\title{
The effect of CAPN1 and CAST gene variations on meat quality traits in Finnish Aberdeen Angus and Nordic Red Cattle populations
}

\author{
Terhi Iso-Touru' ${ }^{1}$, Maiju Pesonen², Daniel Fischer ${ }^{1}$, Arto Huuskonen ${ }^{3}$ and Anu Sironen ${ }^{1}$ \\ ${ }^{1}$ Production systems, Natural Resources Institute Finland (Luke), Myllytie 1, FI-31600 Jokioinen, Finland \\ ${ }^{2}$ Production systems, Natural Resources Institute Finland (Luke), Survontie 9A, FI-40500 Jyväskylä, Finland \\ ${ }^{3}$ Production systems, Natural Resources Institute Finland (Luke), Halolantie 31A, FI-71750 Maaninka, Finland \\ e-mail: terhi.iso-touru@luke.fi
}

\begin{abstract}
High meat quality and specifically meat tenderness are desired traits by the consumers, however the environmental impact of meat production is becoming a relevant factor in the industry. Therefore, breeding of dual purpose cattle breeds may answer the high demand of meat production in the future. In this study we identified statistical differences between genotypes of CAST and CAPN1 gene variants with meat quality traits in a dairy breed (Nordic Red Cattle) and compared the results with beef breed (Aberdeen Angus). Our results show that the favorable alleles have not been selected in the studied dairy breed and thus could be used as a tool for improvement of meat quality. The genes were associated with specific meat quality traits (i.e. sensory juiciness, marbling score and meat color) also in the dairy breed. This supports the utility of known meat quality associated genetic variants to improve meat quality in dairy breeds.
\end{abstract}

Key words: meat production, dairy cattle, beef cattle, $\mu$-calpain, calpastatin

\section{Introduction}

The consumption of animal-based food proteins is predicted to increase (FAO 2011), which emphasizes the importance to improve the environmental performance of livestock system (Herrero et al. 2013). Vellinga and de Vries (2018) evaluated four commonly used mitigation strategies for dairy systems and concluded that dual purpose systems can be advantageous over specialized dairy systems. Therefore, breeding of high quality dual purpose cattle breeds could answer the demand of meat production in the future.

Meat tenderness is considered as the most important meat quality trait (Lian et al. 2012). Meat tenderization is a complex process affected by several elements including pre-and post-slaughter factors and genetic background (Lian et al. 2012). Post-mortem tenderization of the meat is due to enzymatic degradation of myofibrillar proteins. The CAPN system plays a major role in this degradation since $\mu$-calpain (CAPN1) gene encodes $\mu$-calpain protease that is responsible for degradation of myofibrillar proteins (Koohmaraie 1996, Lian et al. 2012) whereas calpastatin protein encoded by calpastatin (CAST) gene binds directly to $\mu$-calpain inhibiting its activity (Barendse et al. 2007).

In this study, we aimed to analyze the allelic and genotypic frequencies of CAPN1 and CAST genes in two different cattle breeds, a dairy breed (Nordic Red Cattle, NRC) and a beef breed (Aberdeen Angus, FAA). We genotyped altogether five variations: rs1109555059, rs41255587, rs17871051, rs109221039, and rs 17872050 located in genes CAPN1 and CAST, which have been previously associated with tenderness of meat (Page et al. 2002, White et al. 2005, Schenkel et al. 2006) in several cattle breeds (e.g. Casas et al. 2006, Morris et al. 2006, Johnston and Graser 2010, McClure et al. 2012). To our knowledge, the influence of the CAPN1 and CAST gene variations have not been studied in NRC that is mainly bred for milk production, but can be considered as a dual purpose breed. Therefore, the objective of this study was to evaluate the influence of genetic variation within these genes on meat quality traits and their frequencies in NRC and FAA.

\section{Materials and methods}

\section{Animal material and analyzed meat quality traits}

The study samples consisted of 40 pure-bred NRC bulls and 40 pure-bred FAA bulls from Finland. The FAA bulls were from 14 and the NRC bulls from 21 different sires. Bulls were fed according to EU organic farming regulation (CEC 1999) and kept in the experimental barn at the Natural Resources Institute Finland in Ruukki, Finland 
and managed according to the Finnish legislation regarding the use of animals in scientific experimentation. The average slaughter age was 495 and $514 \mathrm{~d}$ for FAA and NRC, respectively, and slaughtering was done at the Atria Ltd commercial slaughterhouse in Kauhajoki, Finland. The bulls had approximately $18 \mathrm{~h}$ fasting and lairage time before slaughtering. Carcasses were analyzed for hot carcass weight, EUROP conformation and fat score, marbling score (IMF), pH value and meat color (L, a, b) of the loin (longissimus lumborum). The carcasses were classified for conformation and fatness using the EUROP quality classification (EC 2006). After classification carcasses were chilled overnight below $7^{\circ} \mathrm{C}$. On the day after slaughter the carcasses were commercially cut as described by Pesonen et al. (2013). Loin was cut at the level of the first lumbar vertebra, and the $3 \mathrm{~kg}$ loin sample between the first and fifth lumbar vertebra was used for further analysis. Meat quality measurements after $12 \mathrm{~d}$ ageing at $4{ }^{\circ} \mathrm{C}$ were drip loss, Warner-Bratzler shear force, sensory tenderness, sensory juiciness and beef flavor. Carcass and meat quality measurements have been reported fully by Huuskonen et al. (2017).

\section{DNA extraction and sequencing}

DNA was extracted from meat samples using Qiagen blood and tissue kit following manufacturer's instructions. PCR conditions and primer sequences are given in Supplementary file 1. Five genetic single nucleotide polymorphism (SNP) variations were amplified; rs17872050 and rs17871051for CAPN1 and rs41255587, rs109221039 and rs110955059 for CAST. PCR products were separated on a 1\% agarose gel, purified and directly sequenced using the Big Dye terminator cycle sequencing kit (Applied Biosystems). Electrophoresis of sequencing reactions was performed on a 3500xL Genetic Analyzers (Applied Biosystems). Sequences were analyzed with the Sequencher 5.4.6 software (Gene Codes Corporation, USA).

\section{Statistical analysis}

Associations between meat quality phenotypes and genotypes at selected loci were tested using a non-parametrical test tailored for directional alternatives as they are present in association studies (Fischer et al. 2014). The advantages above classical associations tests based on linear models are that the impact of different group sizes is reduced as well as the impact of outliers in the phenotype data. There is a user-friendly version of the test, implemented in the R-package GenomicTools (Fischer 2017).

\section{Results and discussion}

As expected the meat quality based on all analyzed traits was lower in the NRC breed compared to FAA (Suppl. file 2). Our results show that alleles associated with tender meat (Page et al. 2002, White et al. 2005, Schenkel et al. 2006) were more frequent in FAA samples than in NRC samples seen from the low minor allele frequency (MAF) values for non-favorable alleles (Table 1). This indicates that variations investigated in this study are not intensively selected in NRC breed. According to previous studies, SNPs in CAST or CAPN1 genes do not show association for milk yield, protein yield or fat yield (Iso-Touru et al. 2016) or female fertility (Höglund et al. 2015) within NRC breed that might partly explains the lack of selection. For two variations (rs110955059 and rs41255587) alleles in CAST gene predicted to be beneficial were minor alleles in NRC breed. This further demonstrates the lack of selection pressure.

Table 1. Allele frequencies of CAPN1 and CAST variations in studied Finnish Aberdeen Angus (FAA) and Nordic Red Cattle (NRC) populations

\begin{tabular}{lccccccc}
\hline \multicolumn{1}{c}{ SNP } & gene & $\begin{array}{c}\text { SNP } \\
\text { consequence }\end{array}$ & alleles & $\begin{array}{c}\text { minor } \\
\text { allele FAA }\end{array}$ & $\begin{array}{c}\text { minor } \\
\text { allele } \\
\text { NRC }\end{array}$ & $\begin{array}{c}\text { MAF } \\
\text { FAA }\end{array}$ & $\begin{array}{c}\text { MAF } \\
\text { NRC }\end{array}$ \\
\hline rs17871051 & CAPN1 & missense & G/A & A & A & 0.025 & 0.15 \\
rs17872050 & CAPN1 & intron variant & C/T & T & T & 0.138 & 0.35 \\
rs110955059 & CAST & intron variant & C/G & G & C & 0.175 & 0.325 \\
rs41255587 & CAST & 3' UTR variant & G/A & A & G & 0.175 & 0.35 \\
rs109221039 & CAST & 3' UTR variant & A/G & G & G & 0.113 & 0.363 \\
\hline
\end{tabular}

Identified differences ( $p$-value $<0.1$ ) in associated genotypes with certain meat traits are presented in Table 2 , Table 3 and in Supplementary files 3 and 4 . In FAA, differences ( $p$-value $<0.1$ ) were identified between bulls having 
beneficial alleles as homozygous (for variations rs109221039 [CAST], rs1109555059 [CAST], rs41255587 [CAST], and rs17871051 [CAPN1]) compared to those having a single copy of the beneficial allele. Homozygous FAA bulls had higher sensory tenderness and juiciness and lower shear force (Table 2, Suppl. file 2). However, since beneficial alleles seem to be almost fixed in FAA population (Table 1), CAST and CAPN1 gene variations are not a powerful tool for selection.

Table 2. Meat quality traits for FAA showing differences ( $p$-value $<0.1$ ) with CAPN1 and CAST gene variations

\begin{tabular}{|c|c|c|c|c|c|c|c|c|c|}
\hline Trait & SNP & $\begin{array}{c}\text { SNP } \\
\text { consequence }\end{array}$ & $p$-value & AA mean & $\mathrm{n}(\mathrm{AA})$ & $\mathrm{AB}$ mean & $n(A B)$ & BB mean & $\mathrm{n}(\mathrm{BB})$ \\
\hline shear force & rs109221039 & 3' UTR variant & 0.043 & 48.35 (sd 8.71) & 31 & $\begin{array}{c}54.68 \\
(\mathrm{sd} 8.26)\end{array}$ & 9 & - & - \\
\hline shear force & rs1109555059 & intron variant & 0.057 & 47.68 (sd 7.55) & 26 & $\begin{array}{c}53.66 \\
\text { (sd 10.19) }\end{array}$ & 14 & - & - \\
\hline shear force & rs41255587 & 3' UTR variant & 0.057 & 47.68 (sd 7.55) & 26 & $\begin{array}{c}53.66 \\
\text { (sd 10.19) }\end{array}$ & 14 & - & - \\
\hline sensory juiciness & rs109221039 & 3' UTR variant & 0.063 & $5.79(\mathrm{sd} 0.32)$ & 31 & $\begin{array}{c}5.57 \\
\text { (sd 0.28) }\end{array}$ & 9 & - & - \\
\hline $\begin{array}{l}\text { sensory } \\
\text { tenderness }\end{array}$ & rs17871051 & missense & 0.034 & $5.81(\mathrm{sd} 0.4)$ & 38 & $\begin{array}{c}5.1 \\
\text { (sd 0.28) }\end{array}$ & 2 & - & - \\
\hline sensory juiciness & rs17871051 & missense & 0.092 & 5.35 (sd 0.07) & 38 & $\begin{array}{c}5.76 \\
\text { (sd 0.31) }\end{array}$ & 2 & - & - \\
\hline
\end{tabular}

In NRC breed, bulls that were homozygous for beneficial alleles (rs1109555059 [CAST] rs109221039 [CAST], rs41255587 [CAST), and rs17872050 [CAPN1]) had trend for more yellow tones in meat color, higher sensory juiciness and higher marbling score ( $p$-value $<0.1$, Table 3, Suppl. file 4 ) but no difference was found for tenderness and shear force. The results obtained for FAA are consistent with the earlier studies, but results from NRC are more discordant.

Table 3. Meat quality traits for NRC showing differences ( $p$-value $<0.1$ ) with CAPN1 and CAST gene variations

\begin{tabular}{|c|c|c|c|c|c|c|c|c|c|}
\hline Trait & SNP & $\begin{array}{c}\text { SNP } \\
\text { consequence }\end{array}$ & $p$-value & AA mean & $n(A A)$ & $A B$ mean & $\mathrm{n}(\mathrm{AB})$ & BB mean & $n(B B)$ \\
\hline color b & rs1109555059 & intron variant & 0.013 & $\begin{array}{c}5.36 \\
\text { (sd } 0.73 \text { ) }\end{array}$ & 5 & $\begin{array}{c}6.15 \\
\text { (sd 0.97) }\end{array}$ & 16 & $\begin{array}{c}6.49 \\
\text { (sd 1.4) }\end{array}$ & 19 \\
\hline sensory juiciness & rs1109555059 & intron variant & 0.025 & $\begin{array}{c}5.68 \\
\text { (sd 0.34) }\end{array}$ & 5 & $\begin{array}{c}5.43 \\
\text { (sd 0.43) }\end{array}$ & 16 & $\begin{array}{c}5.38 \\
\text { (sd 0.32) }\end{array}$ & 19 \\
\hline color a & rs1109555059 & intron variant & 0.04 & $\begin{array}{l}19.82 \\
(\mathrm{sd} 2.1)\end{array}$ & 5 & $\begin{array}{c}21.34 \\
\text { (sd 2.13) }\end{array}$ & 16 & $\begin{array}{c}21.91 \\
\text { (sd 2.44) }\end{array}$ & 19 \\
\hline IMF & rs109221039 & 3' UTR variant & 0.052 & $\begin{array}{c}1.33 \\
(\mathrm{sd} 0.7)\end{array}$ & 18 & $\begin{array}{c}1.3 \\
\text { (sd 0.55) }\end{array}$ & 15 & $\begin{array}{c}1.11 \\
\text { (sd 1.03) }\end{array}$ & 7 \\
\hline color b & rs41255587 & 3' UTR variant & 0.093 & $\begin{array}{c}5.36 \\
\text { (sd 0.73) }\end{array}$ & 5 & $\begin{array}{c}6.39 \\
\text { (sd 1.16) }\end{array}$ & 18 & $\begin{array}{c}6.27 \\
\text { (sd 1.31) }\end{array}$ & 17 \\
\hline sensory juiciness & rs41255587 & 3' UTR variant & 0.065 & $\begin{array}{c}5.68 \\
\text { (sd } 0.34)\end{array}$ & 17 & $\begin{array}{c}5.41 \\
\text { (sd } 0.42 \text { ) }\end{array}$ & 18 & $\begin{array}{c}5.4 \\
\text { (sd } 0.33)\end{array}$ & 5 \\
\hline color b & rs 17872050 & intron variant & 0.05 & $\begin{array}{c}5.96 \\
\text { (sd 0.98) }\end{array}$ & 13 & $\begin{array}{c}6.26 \\
\text { (sd 1.27) }\end{array}$ & 26 & $\begin{array}{c}8.3 \\
\text { (sd NA) }\end{array}$ & 1 \\
\hline
\end{tabular}

$\mathrm{MAF}=$ minor allele frequency. Allele marked in $\mathrm{A}$ is the beneficial allele for meat tenderness (based on the literature). $\mathrm{AA}=$ homozygote for allele $A ; A B=$ heterozygote for allele $A ; B B=$ homozygote for allele $B$; sd =standard error; IMF = marbling score; $a$ = redness; $b=$ yellowness

The large variation of meat quality traits in NRC could be a result of minor selection pressure on these traits. The income from beef has been generally low for dairy farms in Finland and this has reduced motivation to improve beef quality traits of dairy herds (Hietala and Juga 2017). Therefore beef traits are not used for dairy cattle breeding schemes (Hietala and Juga 2017) and they are not included in the current Nordic Total Merit (NTM) index for NRC (Kargo et al. 2014). However, Hietala and Juga (2017) concluded that in production systems similar to Finland, where the majority of produced beef originates from dairy herds and beef production fall below consumption, adding beef traits in the breeding program for dairy breeds could enable more sustainable and profitable milk and beef production. 


\section{Conclusions}

In conclusion, there were differences in NRC in various meat quality traits depending on the genotype individual had for CAST or CAPN1 gene variations, which indicates a possible selection tool for meat quality in this population. However, since the causality of these variations has not been demonstrated, the effects should be studied in larger population and associations confirmed.

Our study indicates that in Finnish Aberdeen Angus population the known variations have low frequencies for non-favorable alleles and thus selection for the favorable allele does not benefit the population. However, in dairy breed (NRC) the MAFs are higher suggesting that known meat quality associated variations could be used for selection to produce dual purpose cattle breed. Furthermore, at least the analyzed gene variations have not been shown to associate with milk production traits or with female fertility, which introduce the possibility to improve meat quality in NRC without compromising milk production.

\section{Supplementary material}

Supplementary file 1. Primer names, sequences, SNPs within the PCR amplicon, PCR product length, used PCR enzyme and PCR conditions

Supplementary file 2. Boxplot figures from all measured traits shown per breed

Supplementary file 3. Boxplot figures from variations having $p$-value $<0.10$ for Finnish Aberdeen Angus

Supplementary file 4 . Boxplot figures from variations having $p$-value $<0.10$ for Nordic Red Cattle

\section{Acknowledgements}

This study was partially funded by the Centre for Economic Development, Transport and the Environment for Northern Ostrobothnia, A-Farmers Ltd., HKScan Finland Ltd. and Snellmanin Lihanjalostus Ltd. Technical assistance of Jonna Tabell, Jouni Virta and Anneli Virta is greatly appreciated.

\section{References}

Barendse, W., Harrison, B.E., Hawken, R.J., Ferguson, D.M., Thompson, J.M., Thomas, M.B. \& Bunch, R.J. 2007. Epistasis between calpain 1 and its inhibitor calpastatin within breeds of cattle. Genetics 176: 2601-2610. https://doi.org/10.1534/genetics.107.074328

Casas, E., White, S.N., Wheeler, T.L., Shackelford, S.D., Koohmaraie, M., Riley, D.G., Chase, C.C.,Jr, Johnson, D.D. \& Smith, T.P. 2006. Effects of calpastatin and micro-calpain markers in beef cattle on tenderness traits. Journal of Animal Science 84: 520-525. https://doi.org/10.2527/2006.843520x

EC 2006. Council Regulation (EC) No 1183/2006 of 24 July 2006 concerning the Community scale for the classification of carcasses of adult bovine animals. The Official Journal of the European Union L214: 1-6.

FAO 2011. Mapping supply and demand for animal-source foods to 2030, by T.P. Robinson \& F. Pozzi.Animal Production and Health Working Paper. No. 2. Rome.

Fischer, D., Oja, H., Schleutker, J., Sen, P. \& Wahlfors, T. 2014. Generalized Mann-Whitney Type Tests for Microarray Experiments. Scandinavian Journal of Statistics 41: 672-692. https://doi.org/10.1111/sjos.12055

Fischer, D. 2017. The R-package GenomicTools for multifactor dimensionality reduction and the analysis of (exploratory) Quantitative Trait Loci. Computer Methods and Programs in Biomedicine 151: 171-177. https://doi.org/10.1016/j.cmpb.2017.08.012

Herrero, M., Havlik ,P., Valin, H., Notenbaert, A., Rufino, M.C., Thornton, P.K., Blummel, M., Weiss F., Grace, D. \& Obersteiner, M. 2013. Biomass use, production, feed efficiencies, and greenhouse gas emissions from global livestock systems. Proceedings of the National Academy of Sciences of the United States of America 110: 20888-20893. https://doi.org/10.1073/pnas.1308149110

Hietala, P. \& Juga, J. 2017. Impact of including growth, carcass and feed efficiency traits in the breeding goal for combined milk and beef production systems. Animal 11: 564-573. https://doi.org/10.1017/S1751731116001877

Höglund, J.K., Buitenhuis, B., Guldbrandtsen, B., Lund, M.S. \& Sahana, G. 2015. Genome-wide association study for female fertility in Nordic Red cattle. BMC genetics 16. https://doi.org/10.1186/s12863-015-0269-x

Huuskonen, A., Pesonen, M. \& Honkavaara, M. 2017. Effects of replacing timothy silage by alsike clover silage on performance, carcass traits and meat quality of finishing Aberdeen Angus and Nordic Red bulls. Grass and Forage Science 72: 220-233. https:// doi.org/10.1111/gfs. 12247

Iso-Touru, T., Sahana, G., Guldbrandtsen, B., Lund, M.S. \& Vilkki, J. 2016. Genome-wide association analysis of milk yield traits in Nordic Red Cattle using imputed whole genome sequence variants. BMC genetics 17. https://doi.org/10.1186/s12863-016-0363-8

Johnston, D.J. \& Graser, H.U. 2010. Estimated gene frequencies of GeneSTAR markers and their size of effects on meat tenderness, marbling, and feed efficiency in temperate and tropical beef cattle breeds across a range of production systems. Journal of Animal Science 88: 1917-1935. https://doi.org/10.2527/jas.2009-2305 
Kargo, M., Hjortø, L., Toivonen, M., Eriksson, J.A., Aamand, G.B. \& Pedersen, J. 2014. Economic basis for the Nordic Total Merit index. Journal of Dairy Science 97: 7879-7888. https://doi.org/10.3168/jds.2013-7694

Koohmaraie, M. 1996. Biochemical factors regulating the toughening and tenderization processes of meat. Meat Science 43S1: 193-201.

Lian, T., Wang, L. \& Liu, Y. 2012. A new insight into the role of calpains in post-mortem meat tenderization in domestic animals: A review. Asian-Australasian Journal of Animal Sciences 26: 443-454. https://doi.org/10.5713/ajas.2012.12365

McClure, M.C., Ramey H.R., Rolf, M.M., McKay, S.D., Decker, J.E., Chapple, R.H., Kim, J.W., Taxis, T.M., Weaber, R.L., Schnabel, R.D. \& Taylor, J.F. 2012. Genome-wide association analysis for quantitative trait loci influencing Warner-Bratzler shear force in five taurine cattle breeds. Animal Genetics 43: 662-673. https://doi.org/10.1111/j.1365-2052.2012.02323.x

Morris, C.A., Cullen, N.G., Hickey, S.M., Dobbie, P.M., Veenvliet, B.A., Manley, T.R., Pitchford, W.S., Kruk, Z.A., Bottema, C.D. \& Wilson, T. 2006. Genotypic effects of calpain 1 and calpastatin on the tenderness of cooked M. longissimus dorsi steaks from Jersey $x$ Limousin, Angus and Hereford-cross cattle. Animal Genetics 37: 411-414. https://doi.org/10.1111/j.1365-2052.2006.01483.x

Page, B.T., Casas, E., Heaton, M.P., Cullen, N.G., Hyndman, D.L., Morris, C.A., Crawford, A.M., Wheeler, T.L., Koohmaraie, M., Keele, J.W. \& Smith, T.P. 2002. Evaluation of single-nucleotide polymorphisms in CAPN1 for association with meat tenderness in cattle. Journal of Animal Science 80: 3077-3085. https://doi.org/10.2527/2002.80123077x

Pesonen, M., Honkavaara, M., Kämäräinen, H., Tolonen, T., Jaakkola, M., Virtanen, V. \& Huuskonen, A. 2013. Effects of concentrate level and rapeseed meal supplementation on performance, carcass characteristics, meat quality and valuable cuts of Hereford and Charolais bulls offered grass silage-barley-based rations. Agricultural and Food Science 22: 151-167. https://doi. org/10.23986/afsci.6703

Schenkel, F.S., Miller S.P., Jiang, Z., Mandell, I.B., Ye, X., Li, H. \& Wilton, J.W. 2006. Association of a single nucleotide polymorphism in the calpastatin gene with carcass and meat quality traits of beef cattle. Journal of Animal Science 84: 291-299. https:// doi.org/10.2527/2006.842291x

Vellinga, T.V. \& de Vries, M. 2018. Effectiveness of climate change mitigation options considering the amount of meat produced in dairy systems. Agricultural Systems 162: 136. https://doi.org/10.1016/j.agsy.2018.01.026

White, S.N., Casas, E., Wheeler, T.L., Shackelford, S.D., Koohmaraie, M., Riley, D.G., Chase, C.C. Jr, Johnson, D.D., Keele, J.W. \& Smith, T.P. 2005. A new single nucleotide polymorphism in CAPN1 extends the current tenderness marker test to include cattle of Bos indicus, Bos taurus, and crossbred descent. Journal of Animal Science 83: 2001-2008. https://doi.org/10.2527/2005.8392001x 